
e-ISSN :

\title{
Sistem Monitoring Besaran Listrik dan Energi Penerangan Jalan Umum Secara Realtime Berbasis Web
}

\author{
Riza Samsinar ${ }^{1}$, Redi Rahman Fitria Mulyadi ${ }^{2}$, Dwi Arief Prambudi ${ }^{3}$ \\ 1) 2) Jurusan Teknik Elektro Fakultas Teknik Universitas Muhammadiyah Jakarta, ${ }^{3)}$ Institut Teknologi Kalimantan \\ 1) 2) Jl. Cempaka Putih Tengah 27 Jakarta Pusat 10510, ${ }^{3)}$ Jalan Sukarno Hatta KM. 15, Karang Joang, Balikpapan Utara, \\ Kota Balikpapan \\ Email: ${ }^{1)}$ riza.samsinar@ftumj.ac.id, ${ }^{2)}$ 2012427013@ftumj.ac.id, ${ }^{3)}$ dwiariefprambudi@gmail.com
}

\begin{abstract}
ABSTRAK
Pengembangan energi terbarukan merupakan suatu penghasil energi yang sudah menggunakan cahaya matahari sebagai bahan bakar utamanya (PLTS) juga menjadi salah satu alternative pembangkit listrik yang ramah lingkungan yang sudah diterapakan pada Penerangan Jalan Umum (PJU). Seiring dengan sudah banyaknya dipasang PJU dengan tenaga surya maka sering ditemukan kerusakan pada unit yang masih dibilang susah dalam pemantauan kerusakannya karena harus melihat langsung ke lokasi yang posisinya susah dijangkau karena cukup tinggi. Oleh karena itu pada penelitian ini bertujuan untuk membuat aplikasi sistem monitoring yang dapat dijadikan alat untuk memonitoring sebuah sistem PJU secara realtime. Aplikasi web yang dimaksud adalah sebuah tampilan web dengan sebuah mikrokontroller arduino yang mengontrol sebuah sistem PJU yang akan tertampil pada halaman web yang dilakukan terhadap parameter-parameter yang ada pada saat operasi sistem PJU sehingga pengendalian dan pengamatan jarak jauh dapat dilakukan dan action dari user pun dapat dilakukan lebih dini ketika kondisi sistem PJU tidak normal.
\end{abstract}

Kata kunci : monitoring, arduino, besaran, listrik

\section{PENDAHULUAN}

Dari beberapa tahun terakhir yang merupakan krisis energi di karenakan pomborosan pemakaian energi listrik mampu memberi dampak yang besar bagi kelangsungan hidup manusia. Energi terlibat pada semua aspek kehidupan [1]. Pemborosan tersebut salah satu di antaranya dari energi listrik di sektor pencahayaan pada lampu. Energi listrik pada lampu-lampu penerangan yang ada di gedunggedung atau dijalan umum bukan hanya mahal biaya operasionalnya namun juga menghasilkan emisi gas rumah kaca yang merusak lingkungan. Salah satu solusi mengatasi permasalahan tersebut adalah penggunaan sistem monitoring Saat ini elektronika berbahan semikonduktor organik menjadi perhatian karena fleksibel dan mudah di proses [2], [3], [4]. PJU untuk memonitoring semua parameter dari solarsel hingga menuju beban pada tiap titik PJU yang terpasang dan terintegrasi melalui jaringan internet. Kelebihan Penelitian ini yaitu pada perancangan sistem monitoring PJU (Penerangan Jalan Umum) berbasis web ini adalah dari segi monitoring yang meliputi sistem sel surya, unit baterai, jaringan yang menggunakan mikrokontroller arduino yang dapat dimonitoring jarak jauh dan terintegrasi dengan semua PJU yang terpasang dengan sistem ini. Sistem ini yang menghubungkan ke jaringan internet, dapat memantau semua parameter secara realtime dalam berbagai kondisi operasi. Memungkinkan user untuk mengetahui lebih dini kondisi PJU, baik dari kondisi normal maupun saat kondisi PJU rusak. Sistem monitoring ini merupakan sebuah aplikasi yang dapat dijadikan alat untuk memonitoring sebuah sistem PJU secara realtime. Aplikasi web yang dimaksud adalah sebuah tampilan web dengan sebuah mikrokontroller arduino yang mengontrol sebuah sistem PJU. Dalam penelitian ini akan difokuskan untuk pengamatan berbagai parameter dan pengolahan data yang akan tertampil pada halaman web. Sistem monitoring pada penelitian ini akan dilakukan terhadap parameter-parameter yang ada pada saat operasi sistem PJU. Dengan adanya program berbasis web, tidak hanya pengendalian dan pengamatan jarak jauh yang dapat dilakukan, namun action dari user dapat dilakukan lebih dini ketika kondisi sistem PJU tidak normal. Adapun tujuan yang ingin dicapai dalam penelitian ini adalah membuat aplikasi sistem monitoring PJU secara realtime, mengimplementasikan sistem monitoring PJU yang berbasis web yang dapat dipantau dari jarak jauh. Adapun batasan-batasan pada penulisan ini adalah :

1. Pembuatan sistem monitoring dalam bentuk web yang diterapkan pada sistem PJU dibatasi dari monitoring parameter peralatan dan akuisisi data parameter yang disimpan dalam database.

2. Kontroler yang digunakan adalah mikrokontroler arduino. 


\section{e-ISSN :}

\section{METODOLOGI}

Adapun metodologi yang dilakukan sehubungan dengan pengerjaan penelitian ini adalah sebagai berikut :

1. Melakukan studi pustaka tentang teknik-teknik yang digunakan yang meliputi beberapa tahap penelitian :

2. Teknik yang digunakan untuk perancangan pengontrolan jarak jauh.

3. Pembuatan arsitektur hardware menggunakan mikrokontroler arduino.

4. Pembuatan arsitektur wireless sistem PJU.

5. Pembuatan server pusat, parameter yang akan tampil pada software disimpan pada database melalui serial port.

6. Data-data yang telah tersimpan di database tersebut selanjutnya diambil untuk ditampilkan pada web base Client Software.

7. Pembuatan software web dilakukan dengan menggunakan pemprograman $H T M L$.

8. Pembuatan perangkat pengontrolan jarak jauh dengan melalui internet sebagai media perantaranya.

9. Sistem monitoring ini akan terhubung dengan server online dengan user interface berbasis web, sehingga pengguna mampu mengakses system melalui jaringan internet.

10. Analisa hasil data web untuk parameterparameter yang digunakan dalam system monitoring secara real-time.

Daya aktif adalah daya yang terpakai untuk melakukan energi sebenarnya. Satuan daya aktif adalah Watt. Daya reaktif adalah jumlah daya yang diperlukan untuk pembentukan medan magnet. Daya semu adalah daya yang dihasilkan oleh perkalian antara tegangan dan arus dalam suatu jaringan. Sigitiga Daya merupakan segitiga yang menggambarkan hubungan matematika antara tipe tipe daya yang berbeda antara daya semu, daya aktif dan daya reaktif berdasarkan prinsip trigonometri.

dimana berlaku hubungan

$\mathrm{S}=\mathrm{V} \cdot \mathrm{IS}=$ Daya Semu(VA)

$\mathrm{P}=\mathrm{S} \cdot \operatorname{Cos} \varphi \mathrm{P}=$ Daya Nyata (Watt)

$\mathrm{Q}=\mathrm{S} \cdot \operatorname{Sin} \varphi \mathrm{Q}=$ Daya Reaktif $(\mathrm{VAR})$

Faktor daya didefinisikan sebagai rasio perbandingan antara daya aktif (Watt) dan daya semu (VA) yang digunakan dalam listrik arus bolak balik (AC) atau beda sudut fasa antara V dan I [5],[6],[7],[8]. Jika rangkaian bersifat induktif, arus akan tertinggal dibelakang tegangan dan jika rangkaian bersifat kapasitif, makan arus akan mendahului tegangan [9].

Arduino adalah kit elektronik atau papan rangkaian elektronik open source yang di dalamnya terdapat komponen utama yaitu sebuah chip mikrokontroler dengan jenis $A V R$ dari perusahaan Atmel. Arduino merupakan sebuah mikrokontroler opensource yang bias diprogram dengan mudah [10]. Mikrokontroler itu sendiri adalah chip atau IC (integrated circuit) yang bisa diprogram menggunakan komputer. Tujuan menanamkan program pada mikrokontroler adalah agar rangkaian elektronik dapat membaca input, memproses input tersebut dan kemudian menghasilkan output sesuai yang diinginkan [11]. Wireless Local Area Network (disingkat Wireless LAN atau WLAN) adalah jaringan komputer yang menggunakan frekuensi radio dan infrared sebagai media transmisi data. Wireless LAN sering disebut sebagai jaringan nirkabel atau jaringan wireless. Sistem monitoring merupakan suatu proses untuk mengumpulkan data dari berbagai sumber daya. Biasanya data yang dikumpulkan merupakan data yang real time. Secara garis besar tahapan dalam sebuah sistem monitoring terbagi ke dalam tiga proses besar, yaitu:

1. proses di dalam pengumpulan data monitoring

2. proses di dalam analisis data monitoring

3. proses di dalam menampilkan data hasil monitoring

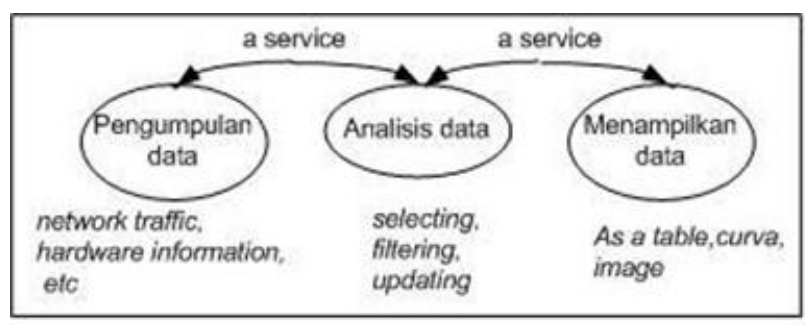

Gambar 1 Proses monitoring.

Pengukuran adalah suatu pembandingan antara suatu besaran dengan besaran lain yang sejenis secara eksperimen dan salah satu besaran dianggap sebagai standar. Dalam pengukuran listrik terjadi juga pembandingan, dalam pembandingan ini digunakan suatu alat bantu (alat ukur). Alat ukur ini sudah dikalibrasi, sehingga dalam pengukuran listrikpun telah terjadi pembandingan. PHP : Hypertext Processor merupakan salah satu bahasa pemrograman di sisi server untuk membuat web dinamis. Bahasa pemrograman PHP diciptakan oleh Rasmus Lerdorf, pada tahun 1995 Lerdorf membuat sebuah alat untuk yang kemudian disebut "Personal Home Page" [12]. PHP sendiri merupakan bahasa pemrograman yang bebas dipergunakan (open source), dan sudah banyak digunakan oleh pengembang website. PHP juga berdiri sebagai platfrom yang mampu dijalankan di berbagai sistem operasi, baik di Windows, UNIX, Linux maupun Mac, dan juga mendukung penggunaan beberapa 
RESISTOR (elektRonika kEndali telekomunikaSI tenaga liSTrik kOmputeR) Vol. 1 No. 1 e-ISSN :

database, salah satunya adalah MySQL. Secara keseluruhan perancangan sistem MONITORING yang dibuat dapat digambarkan seperti flow chart dibawah ini :

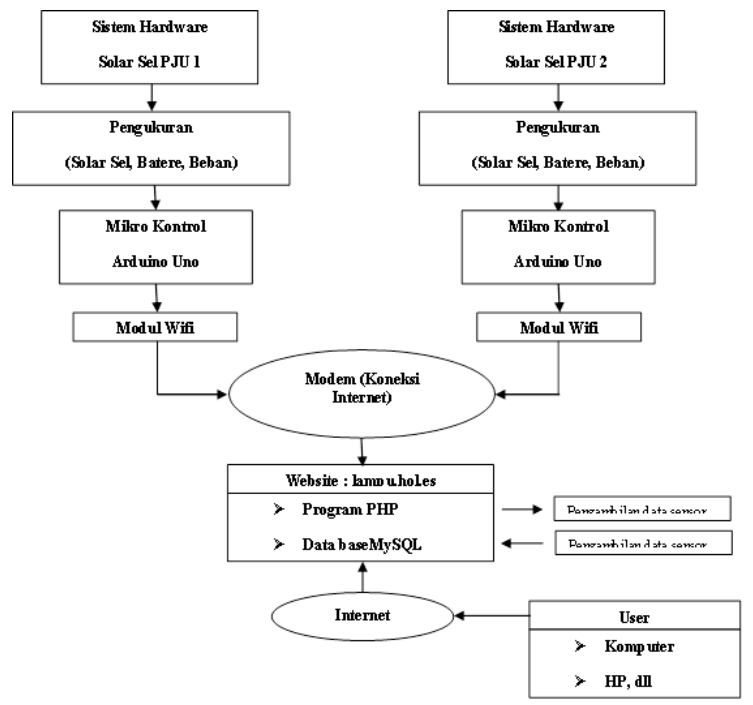

Gambar 2 Diagram alir perancangan system monitoring.

Bagian inti dari desain monitoring ini adalah pengendali mikro single-board bernama Arduino Uno $R 3$ yaitu papan mikrokontroler berbasis ATmega328 yang memiliki jumlah input analog dan digital yang berbeda [13]. Seperti yang ditunjukkan pada Gambar 3.2, Arduino Uno Ini memiliki 14 digital pin input/output (dimana 6 dapat digunakan sebagai output PWM) dan 6 input sebagai analog. MTU (Master Terminal Unit) pada perancangan monitoring ini pada dasarnya adalah sebuah komputer yang memiliki sistem operasi windows yang mana komputer ini bertindak sebagai server database. Komputer server ini menjalankan $S Q L$ Server sebagai database dan menyediakan layanan Web server dengan IIS (Internet Information System) yang dikeluarkan oleh Microsoft dengan menggunakan pemrograman Visual Basic. Pada database memiliki dua relasi, diantaranya adalah data dan grafik. Relasi data dari sistem monitoring digunakan untuk penampungan semua data dari sistem PV. Relasi data ini memiliki berbagai bidang yang didefinisikan oleh sensor tegangan solar cell, sensor tegangan batere, sensor tegangan beban, sensor arus solar cell, sensor arus batere, sensor arus beban. Semua data akan mulai disimpan per 60 menit secara otomatis. Struktur dari relasi tersebut ditunjukkan pada diagram alir berikut.

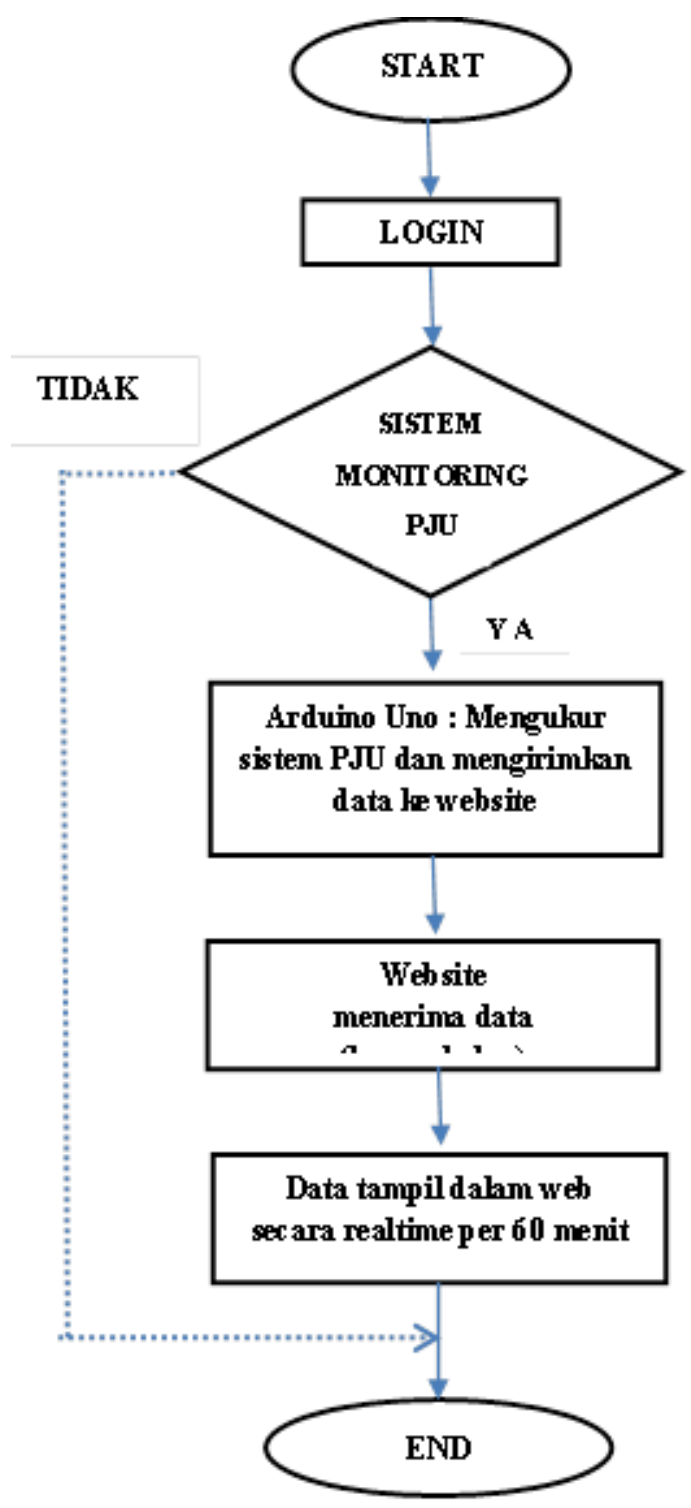

Gambar 3 Real time monitoring. 
RESISTOR (elektRonika kEndali telekomunikaSI tenaga liSTrik kOmputeR) Vol. 1 No. 1 e-ISSN :

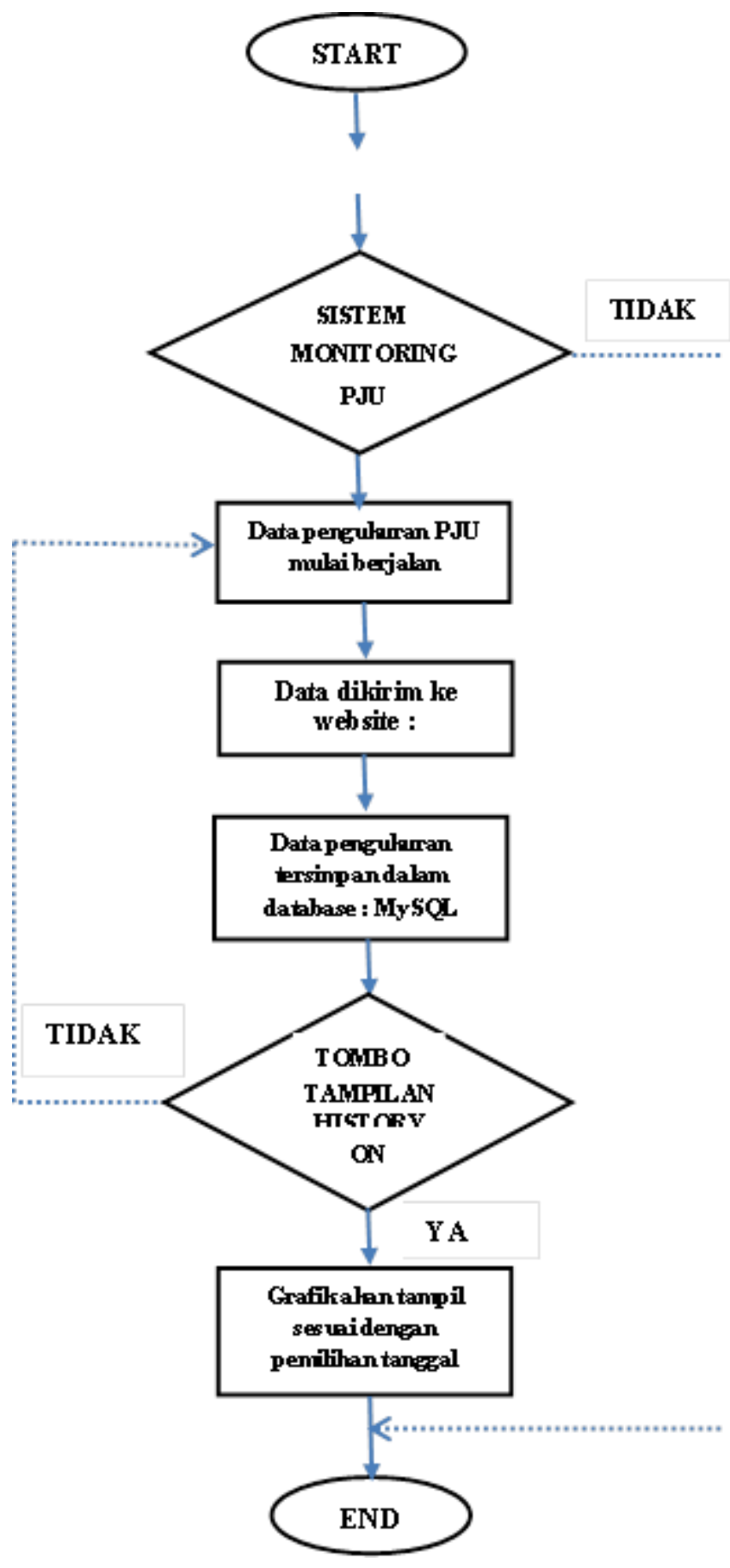

Gambar 4 History monitoring.

\section{HASIL DAN PEMBAHASAN}

Pada bab ini akan dibahas pengujian Sistem Monitoring Besaran Listrik dan Energi Penerangan Jalan Umum Secara Realtime Berbasis Web, baik dari sisi perangkat lunak (software) atau dari sisi perangkat keras (hardware). Pengujian ini dilakukan dengan tujuan untuk mengetahui kinerja dari keseluruhan sistem monitoring yang dirancang. Pengujian ini dilakukan pada setiap bagian perancangan mulai dari pengujian sensor hingga pengujian fungsi sistem Monitoring.
Untuk melakukan pengujian perangkat keras, diperlukan adanya perbandingan antara nilai pengukuran dengan mempergunakan alat ukur standart (telah terkalibrasi oleh badan kalibrasi tertentu) dengan nilai pengukuran pada mikrokontroler arduino.

Sistem Monitoring ini menggunakan 3 sensor tegangan, 3 sensor beban DC yang terdapat pada solar cell, battery dan beban.

Tegangan yang diukur untuk solar cell, battery dan beban memiliki range $0-25 \mathrm{~V}$ DC. Tabel dibawah ini merupakan hasil dari pengujian sensor tegangan. Pengujian ini terdapat 3 sensor tegangan DC yang diuji dan pengujian ini memakai alat ukur Fluke 289 sebagai acuan nilai yang benar. Pengujian ini memiliki parameter Vin (nilai tegangan input dari sensor), Vout (nilai tegangan keluaran sensor) dan Vce (nilai tegangan yang tampil dalam display interface sistem Monitoring).

Sensor arus yang dipakai dalam sistem monitoring PJU ini adalah sensor ACS712-30A yang merupakan sensor yang digunakan untuk pengukuruan arus listrik dan mempunyai kemampuan membaca arus hingga $+/-30$ A. Sensor arus ini dipakai untuk pengukuran arus pada solar cell, battery dan beban. Dalam sensor ini terdapat beberapa port VCC, OUT, dan GND yang dihubungkan pada mikrokontroler Arduino. Untuk VCC dihubungkan ke tegangan 5V, GND dihubungkan ke ground dan OUT adalah tegangan hasil OUT dari sensor ini yang dihubungkan pada port Analog input Arduino. Divais ini terdiri berisi sebuah sirkuit Hall yang linear dan low-offset [14].

Pengukuran arus DC ini dilakukan pada titik arus solar cell, battery dan beban. Berikut adalah pengujian sensor arus pada sistem monitoring.

Dalam penelitian ini daya sel surya dihasilkan dari perkalian sensor tegangan dan arus listrik yang dihasilkan dan telah dilakukan penyetingan terhadap alat ukur standar. Pengujian ini dilakukan pada pukul 01.00 hingga 24.00. Dan terlihat data daya keluaran sel surya seperti tabel dan grafik dibawah ini. 
RESISTOR (elektRonika kEndali telekomunikaSI tenaga liSTrik kOmputeR) Vol. 1 No. 1 e-ISSN :

Tabel 1 Hasil pengujian sensor tegangan dan arus.

\begin{tabular}{|c|c|c|c|c|c|c|c|}
\hline \multirow[b]{2}{*}{ No } & \multirow[b]{2}{*}{ Jam } & Tegangan & Tegangan & Tegangan & Arus & Arus & Arus \\
\hline & & $\begin{array}{c}\text { (S ensor } \\
\text { Solar Cell) }\end{array}$ & $\begin{array}{l}\text { (Sensor } \\
\text { Battery) }\end{array}$ & $\begin{array}{l}\text { (Sensoer } \\
\text { Beban) }\end{array}$ & $\begin{array}{c}\text { (S ensor } \\
\text { S olar Cell) }\end{array}$ & $\begin{array}{l}\text { (S ensor } \\
\text { Battery) }\end{array}$ & $\begin{array}{c}\text { (S ensor } \\
\text { Beban) }\end{array}$ \\
\hline 1 & 01.00 & 3.30 & 3.30 & 3.27 & -0.140 & -0.19 & -0.04 \\
\hline 2 & 02.00 & 3.27 & 3.25 & 3.23 & -0.140 & -0.18 & -0.05 \\
\hline 3 & 03.00 & 3.23 & 3.20 & 3.20 & -0.140 & -0.17 & -0.05 \\
\hline 4 & 04.00 & 3.18 & 3.15 & 3.18 & -0.140 & -0.16 & -0.06 \\
\hline 5 & 05.00 & 3.18 & 3.15 & 3.15 & -0.140 & -0.16 & -0.06 \\
\hline 6 & 06.00 & 3.27 & 3.27 & 3.27 & -0.170 & -0.15 & -0.05 \\
\hline 7 & 07.00 & 4.47 & 4.45 & 4.33 & -0.290 & -0.13 & 0.03 \\
\hline 8 & 08.00 & 5.06 & 5.08 & 5.08 & -0.340 & -0.13 & 0.06 \\
\hline 9 & 09.00 & 5.55 & 5.47 & 5.45 & -0.490 & -0.12 & 0.17 \\
\hline 10 & 10.00 & 5.96 & 5.89 & 5.91 & -0.600 & 0.09 & 0.09 \\
\hline 11 & 11.00 & 6.35 & 6.31 & 6.23 & -0.600 & -0.17 & 0.29 \\
\hline 12 & 12.00 & 5.62 & 5.55 & 5.55 & -0.420 & -0.22 & 0.18 \\
\hline 13 & 13.00 & 5.67 & 5.57 & 5.60 & -0.380 & -0.16 & 0.12 \\
\hline 14 & 14.00 & 5.43 & 5.40 & 5.30 & -0.330 & -0.18 & 0.1 \\
\hline 15 & 15.00 & 5.28 & 5.18 & 5.23 & -0.250 & -0.22 & 0.06 \\
\hline 16 & 16.00 & 5.21 & 5.18 & 5.18 & -0.200 & -0.23 & 0.03 \\
\hline 17 & 17.00 & 5.18 & 5.08 & 5.08 & -0.150 & -0.19 & -0.03 \\
\hline 18 & 18.00 & 3.86 & 3.86 & 3.86 & -0.130 & -0.16 & -0.06 \\
\hline 19 & 19.00 & 3.47 & 3.57 & 3.57 & -0.140 & -0.15 & -0.07 \\
\hline 20 & 20.00 & 3.45 & 3.45 & 3.45 & -0.130 & -0.14 & -0.07 \\
\hline 21 & 21.00 & 3.40 & 3.37 & 3.40 & -0.130 & -0.14 & -0.08 \\
\hline 22 & 22.00 & 3.35 & 3.23 & 3.35 & -0.130 & -0.14 & -0.08 \\
\hline 23 & 23.00 & 3.32 & 3.30 & 3.25 & -0.140 & -0.14 & -0.08 \\
\hline 24 & 24.00 & 3.32 & 3.30 & 3.30 & -0.130 & -0.13 & -0.08 \\
\hline
\end{tabular}

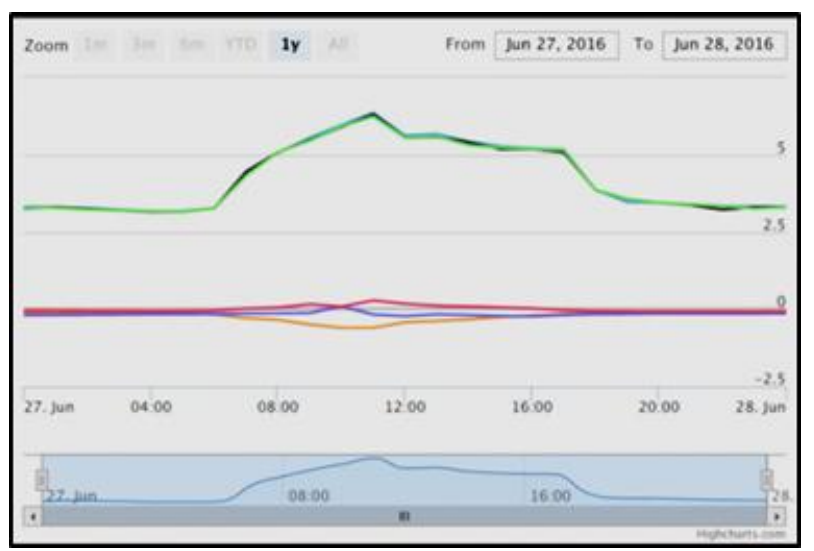

Gambar 5 Daya harian.

Berdasarkan grafik diatas daya yang dihasilkan tertinggi antara pukul 07.00 hingga pukul 17.00 (10 Jam). Daya yang dihasilkan sel surya memiliki nilai tertinggi 6.35 Volt dan nilai terendah 3.18 Volt.

Pada pengujian perangkat lunak, diperlukan untuk melihat kecepatan respon dalam menampilkan data serial arduino, baik yang secara real time maupun data yang telah tersimpan dalam database. Dan dalam pengujian ini menggunakan aplikasi web dengan pemrograman PHP. Hosting web yang dipakai adalah HOSTINGER. Real Time : Speed modem 4G Smartfren 10 mbps dan data yang dikirimkan $100 \mathrm{~kb} / \mathrm{unit}$ PJU. History : Data-data hasil sensor yang disimpan setiap 60 menit secara otomatis.

\section{KESIMPULAN}

Bisa diambil kesimpulan bahwa desain dari sistem monitoring PJU akan sangat memudahkan dalam mengontrol PJU jarak jauh dan memudahkan dalam pemantauan kerusakannya, dengan perancangan hardware mikrokontroler arduino maka kondisi perangkat dari PJU bisa dikirimkan melalui web sehingga akan memudahkan dalam memonitoring system tersebut, pada pengujian sensor tegangan DC diatas memiliki selisih rata-rata $3 \%$.

Berdasarkan hasil pengujian sistem monitoring yang dihasilkan tertinggi antara pukul 07.00 hingga pukul 17.00 (10 Jam). Daya yang dihasilkan sel surya memiliki nilai tertinggi 6.35 Volt dan nilai terendah 3.18 Volt. Pengujian menu system aplikasi web memiliki rata-rata waktu respon yang masih baik sekitar 1.545 detik

\section{DAFTAR PUSTAKA}

[1] Budiyanto and Fadliondi, "The Improvement of Solar Cell Output Power Using Cooling and Reflection from Mirror," Int. J. Power Electron. Drive Syst., vol. 8, no. 3, pp. 13201326, 2017.

[2] Fadliondi, M. K. Biddinika, and S.-I. Ohmi, "The humidity dependence of pentacene organic metal-oxide-semiconductor fieldeffect transistor," Telkomnika (Telecommunication Comput. Electron. Control., vol. 15, no. 2, pp. 578-583, 2017.

[3] F. Fadliondi and B. Budiyanto, "Transistor Efek Medan Berbasis Semikonduktor Organik Pentacene untuk Sensor Kelembaban," J. Nas. Tek. Elektro dan Teknol. Inf., vol. 6, no. 2, pp. 204-209, 2017.

[4] Fadliondi, H. Isyanto, and P. G. Chamdareno, "The comparison of organic field effect transistor (OFET) structures," in 2017 2nd International Conference on Frontiers of Sensors Technologies (ICFST), 2017, pp. 6-9.

[5] M. R. Fachri, I. D. Sara, and Y. Away, "Pemantauan Parameter Panel Surya Berbasis Arduino secara Real Time," J. Rekayasa Elektr., vol. 11, no. 4, p. 123, 2015.

[6] Abhinav Sharma, Saleem Khan, Shavet Sharma, and Parveen Lehana, "Dependence of Power Factor on Inductive Loads for Microcontroller based Power Systems In," IOSR J. Electr. Electron. Eng. , vol. 7, no. 2, pp. 30-35, 2013.

[7] A. So, W. L. Chan, and S. K. M. Tsang, "On the total power factor of lift systems," Build. Serv. Eng. Res. Technol., vol. 38, no. 4, pp. 436-449, Jan. 2017. 
RESISTOR (elektRonika kEndali telekomunikaSI tenaga liSTrik kOmputeR) Vol. 1 No. 1 e-ISSN :

[8] T. S. Jadhav, C. A.M, and D. B.T, "Design and Implementation of an Isolated Power Factor Correction using Full Bridge Topology," Ijireeice, vol. 5, no. 6, pp. 137-141, 2017.

[9] S. Khanchi and V. K. Garg, "Power Factor Improvement of Induction Motor by Using Capacitors," Int. J. Eng. Trends Technol., vol. 4, no. 7, pp. 2967-2971, 2013.

[10] L. Louis, "WORKING PRINCIPLE OF ARDUINO AND USING IT AS A TOOL FOR STUDY AND RESEARCH Leo," Int. $J$. Control. Autom. Commun. Syst., vol. 1, no. 2, pp. 21-29, 2016.

[11] A. Tsagaris and D. G. Triantafyllidis, "Data monitoring system for supervising the performance assessment of a photovoltaic park," CINTI 2012 - 13th IEEE Int. Symp. Comput. Intell. Informatics, Proc., pp. 385389, 2012.

[12] M. T. Chulkamdi and S. Purnomo, "Perancangan Dan Implementasi Game Interaktif Pengenalan Huruf Dan Angka Untuk Media Kabupaten Blitar," J. Antivirus, vol. 10, no. 1, pp. 17-23, 2016.

[13] R. H. M. Ganesh, K. A. Udhaya, and P. P. Sathya, "Stepper Motor Control using ARDUINO ATMEGA - 328 MicroController saranathan College of Engineering," Int. J. Sci. Res. Dev., vol. 2, no. 12, pp. $778-$ 780, 2015.

[14] V. Tadavarthy and A. Broota, "Smart Power Monitoring \& Analysis," Int. J. Sci. Res., vol. 5, no. 7, pp. 1627-1630, 2016. 